\title{
Influence of Fungicide Application Timings on the Management of Bermudagrass Spring Dead Spot Caused by Ophiosphaerella herpotricha
}

\author{
N. R. Walker, Department of Entomology and Plant Pathology, Oklahoma State University, Stillwater, OK 74078
}

\begin{abstract}
Walker, N. R. 2009. Influence of fungicide application timings on the management of bermudagrass spring dead spot caused by Ophiosphaerella herpotricha. Plant Dis. 93:1341-1345.

Spring dead spot, caused by Ophiosphaerella spp., is the most important disease of bermudagrass (Cynodon dactylon and $C$. dactylon $\times C$. transvaalensis) where cool temperatures induce dormancy. Field plot studies were conducted from 2004 to 2008 to determine the frequency and timings of fungicide applications for control of the disease. The fungicide treatments included tebuconazole applied two, three, or four times in the fall, once in the spring plus twice in the fall, or twice in the spring and twice in the fall. Propiconazole treatments consisted of one spring, one spring and one fall, one spring and two fall, or two fall applications. Disease severity in plots treated three or four times in the fall with tebuconazole was significantly lower than for those not treated. Based on the change in patch size prior to treatment, patches in plots treated four times with tebuconazole were smaller than in the previous year and were smaller than patches treated once in the spring and twice in the fall or twice in the fall. Plots receiving two fall, one spring and one fall, or one spring and two fall applications of propiconazole had less disease than plots treated once in the spring or plots not treated. Based on the change in plot area prior to treatment, plots receiving two fall, one spring and one fall, or one spring and two fall propiconazole applications had a reduction in plot area expressing symptoms of disease. These studies demonstrated that two fall or one spring and one fall application appear to provide the most effective and cost effective disease control in an integrated approach to managing the disease. The study also demonstrates the importance of disease severity assessment prior to treatment in evaluating the efficacy of a control measure for spring dead spot.
\end{abstract}

Bermudagrass (Cynodon dactylon (L.) Pers. and C. dactylon $\times$ C. transvaalensis Burtt-Davy) is a commonly used turfgrass species in the southern United States. Uses of bermudagrass include plantings on golf course fairways, tee boxes, and roughs, athletic fields, and residential and commercial lawns. The upper region of the southern United States where bermudagrass is grown is known as the "transition zone". In this region, as air and soil temperatures cool in late autumn, bermudagrass plants enter a state of dormancy. Plants remain dormant until spring, when soil temperatures are sufficiently warm to permit regrowth of the turf from rhizomes and stolons.

The most devastating and important disease of bermudagrass is spring dead spot $(9,13)$ in regions where the grass enters cool-temperature induced dormancy. In Oklahoma and surrounding regions, the disease is primarily caused by Ophiosphaerella herpotricha (Fr.:Fr.) J. Walker $(19,23,28)$. However, O. korrae (J. Walker \& A.M. Smith) Shoemaker \& C.E. Bab-

Corresponding author: N. R. Walker

E-mail: nathan.walker@okstate.edu

Accepted for publication 24 August 2009.

doi:10.1094/PDIS-93-12-1341

(C) 2009 The American Phytopathological Society cock can occasionally be found in the region and is more prevalent in the southeastern and gulf coastal states of the United States $(4,6)$. In Australia, New Zealand, and occasionally in the western United States, the principle causal agent has been $O$. narmari (J. Walker \& A.M. Smith) Wetzel, Hubert \& Tisserat $(14,15,24)$.

In the United States, symptoms of spring dead spot typically appear in the spring when the turf breaks dormancy and transitions from the previous year's dead, brown foliage to green, growing plants. Diseased plants do not survive winter dormancy, resulting in ring-, circular-, or irregular-shaped patches of dead grass that are sunken and range in size from $5 \mathrm{~cm}$ to $>1 \mathrm{~m}$ diameter. Patches can differ in size in the same stand of turf, persist in the same location, and typically enlarge from yearto-year $(9,13)$. Regrowth of bermudagrass into the affected area occurs from surviving grass in or around the periphery of the patches; however, growth of the turf into the patches can be slowed by cool temperatures, competition from weeds, or herbicides that inhibit root growth.

An integrated approach for the management of spring dead spot is most effective for the long-term management of the disease. Selection of a disease resistant bermudagrass cultivar can reduce the severity and damage caused by the disease (1). However, more resistant cultivars are often not selected because of the following: (i) undesirable turf characteristics, (ii) the cost of changing cultivars, (iii) limited availability of resistant cultivars, and (iv) disease resistance to spring dead spot was not a consideration during the cultivar selection process.

Cultural management of bermudagrass can influence the severity of the disease. Intensively managed bermudagrass, or stands that receive frequent mowing, irrigation, fertility, and herbicide inputs, are more severely damaged by the disease (13). Excessive nitrogen fertilization during the growing season, particularly in the autumn can increase disease severity $(8,11)$. Mowing height, fertilizer formulation, soil type, and soil disturbance have also been reported to influence the severity of disease $(5,10,12,18,29)$.

Efforts to minimize the severity of spring dead spot using cultural management efforts may not provide an acceptable level of disease control. Where high quality bermudagrass is desired in the spring, a fungicide program may be needed. Fungicide applications have been recommended in the fall prior to plant dormancy. However, the effectiveness of fungicide applications in the fall has been inconsistent. These observations have resulted in attempts by researchers to improve the timing, frequency, or method of fungicide application $(2,3,7,20,21,25)$.

A reduction in disease severity caused by $O$. korrae was reported from a single application of fenarimol at $2.3 \mathrm{~kg} / \mathrm{ha}$ in early October (27). A similar reduction was observed for fenarimol at $1.53 \mathrm{~kg} / \mathrm{ha}$ in early October and again in early November (20). In Oklahoma, fenarimol at $2.3 \mathrm{~kg} / \mathrm{ha}$, propiconazole at $2.0 \mathrm{~kg} / \mathrm{ha}$, or tebuconazole at $3.1 \mathrm{~kg} / \mathrm{ha}$ applied repeatedly from late August to early October reduced disease severity caused by $O$. herpotricha (25). The rate and timing of fenarimol applications were examined for suppression of spring dead spot caused by O. korrae $(3,21)$. Two applications, approximately 2 weeks apart, were made beginning in late August, early October, late October, or early November. Disease severity did not differ for any of the application timings, but levels of disease differed with the rate of fungicide application. The effect of carrier volume and application method for control of spring dead spot was also examined $(3,21)$. However, there was no difference in the efficacy of the application methods examined. 
Some of the variability in fungicidebased control of spring dead spot may be related to soil temperatures and pathogen activity. It has been suggested that the disease is active in both spring and fall $(4,16,26)$. Soil temperatures from 10 to $20^{\circ} \mathrm{C}$ were suggested to be most conducive for activity of $O$. narmari in Australia (16). It was hypothesized that the pathogen probably was infecting plant roots in both spring and fall when soil temperatures were above $10^{\circ} \mathrm{C}$ (4). In another study, it was suggested that infection and colonization of bermudagrass roots by $O$. herpotricha could occur from 10 to $25^{\circ} \mathrm{C}$ (19). It has also been suggested that the pathogen may have two periods of activity during the year in Oklahoma based on soil temperature data (26). Two periods of disease activity could explain some of the inconsistency reported for studies that have only conducted fall fungicide applications (17). It may be possible to increase the effectiveness of fungicide applications by targeting both periods of disease activity.

The objective of this study was to evaluate the efficacy of increasing the number of fungicide applications using various sequences of fall and spring applications on the control of spring dead spot.

\section{MATERIALS AND METHODS}

Inoculated plots. Studies were conducted from 2004 to 2006 at the Oklahoma State University Plant Pathology Research Farm in Stillwater, OK. The site was a Norge clay loam soil with pH 6.9 containing a stand of bermudagrass (cv. Jackpot) that was established in 2000 using sprigs. The site was inoculated in 2001 at 88 different locations, each with $10 \mathrm{~g}$ of wheat seeds colonized by $O$. herpotricha on a $1.52-\mathrm{m}$ in-row spacing (26). Mowing height was $5 \mathrm{~cm}$ with irrigation applied two to three times weekly and fertilization occurring one to two times monthly from late April through August at $48.9 \mathrm{~kg} \mathrm{~N} / \mathrm{ha}$ per application. Well-defined, individual spring dead spot patches were present in 2003, and the size of all patches each spring was recorded by covering the stand with a clear plastic tarp and tracing the outline of each patch (26).

In 2004, the fungicide tebuconazole (Lynx, Bayer Environmental Science, Research Triangle Park, NC) was applied at $3.1 \mathrm{~kg} / \mathrm{ha}$ with a $\mathrm{CO}_{2}$ pressurized wheeled sprayer equipped with TX8008 flat fan nozzles and calibrated to deliver 823 liter/ha to plots known to contain a single well-developed spring dead spot patch. Treatments consisted of two, three, and four applications in the fall; one spring and two fall applications; and two spring and two fall applications (Table 1). Nonfungicide-treated plots were used as a control. Immediately following each application, plots were irrigated with 10 to $13 \mathrm{~mm}$ of water. The experimental design was a randomized complete block with four replications. Disease was evaluated in the spring of 2005 on a scale of 1 to 6 , where 1 $=$ no living plants present in patch, $2=$ few surviving plants present in patch, $3=$ up to $50 \%$ of patch area containing living plants, $4=$ up to $75 \%$ of patch area containing living plants, $5=$ more than $75 \%$ of patch containing turfgrass and patch still evident, and $6=$ no evidence of diseased turfgrass. Patch size $\left(\mathrm{m}^{2}\right)$ was determined on 5 May (2005) and the change in patch size was determined from measurements taken the previous year. The study was repeated in 2005; however, treatments were applied to plots that had not been treated with fungicide in the previous 12 months. Disease severity was evaluated in the spring of 2006, patch size $\left(\mathrm{m}^{2}\right)$ was determined on 24 May (2006), and change in patch size was determined as described previously.

Naturally infested field plots. Field studies were conducted from 2006 to 2008 on a golf course fairway in Edmond, OK. The site was a Harrah fine sandy loam soil with a $\mathrm{pH}$ of 7.6 containing a mature stand of bermudagrass (cv. Tifway 419) with a history of spring dead spot. The site was scouted in the spring of 2006 for the purpose of establishing plots with similar levels of disease severity. Mowing height was $1.5 \mathrm{~cm}$, irrigation was applied two to three times weekly, and fertilization oc- curred two to three times per growing season at $48.9 \mathrm{~kg} \mathrm{~N} / \mathrm{ha}$ per application. In 2006, the fungicide propiconazole (Banner MAXX, Syngenta Professional Products, Greensboro, NC) was applied at $2.0 \mathrm{~kg} / \mathrm{ha}$ with a $\mathrm{CO}_{2}$ pressurized wheeled sprayer equipped with TX8008 flat fan nozzles and calibrated to deliver 823 liters/ha to 1.83 by $3.1 \mathrm{~m}$ plots. Two fungicide treatments from studies with inoculated plots and two additional treatments were selected for evaluation in field plots. Treatments consisted of the following: two applications in the fall; one spring and two fall applications; one spring; and one spring and one fall application, respectively (Table 2). Non-fungicide-treated plots were used as a control. Immediately following each application, the study area was irrigated with 10 to $13 \mathrm{~mm}$ of water. The experimental design was a randomized complete block with four replications. Disease severity was evaluated in the spring of 2007 using the previously described method. All plots were photographed using a digital camera at the time of establishment, prior to spring fungicide applications, and again on 16 May 2007. Using the photographs, the percent area of each plot with symptoms of spring dead spot was determined using Assess digital imaging software (version 2.0; American Phytopathological Society, St. Paul, MN).

In 2007, new plots were established in an area adjacent to the previously used plots and photographed. However, due to the limited distribution of disease with similar severities, the length of plots was decreased to $2.1 \mathrm{~m}$. Disease severity was evaluated in the spring of 2008 and plots photographed on 8 May 2008. The percent area of plots with symptoms of spring dead spot was determined as described previously.

For both inoculated plot and naturally infested field studies, statistical analyses were conducted using the GLM procedure with SAS (version 9.1; SAS Institute, Cary, NC) to evaluate treatment effects for the different fungicide treatments and over experiments. Orthogonal contrasts were
Table 1. Dates of tebuconazole applications to inoculated bermudagrass turf plots each containing one spring dead spot patch in 2004 and $2005^{z}$

\begin{tabular}{ll}
\hline Application sequence & Dates \\
\hline 2004 & \\
2 Fall & 27 Aug and 10 Sept \\
3 Fall & 27 Aug, 10 Sept, and 24 Sept \\
4 Fall & 27 Aug, 10 Sept, 24 Sept, and 8 Oct \\
1 Spring and 2 fall & 7 May, 27 Aug, and 10 Sept \\
2 Spring and 2 fall & 7 May, 21 May, 27 Aug, and 10 Sept \\
2005 & \\
2 Fall & 12 Aug and 26 Aug \\
3 Fall & 12 Aug, 26 Aug, and 9 Sept \\
4 Fall & 12 Aug, 26 Aug, 9 Sept, and 23 Sept \\
1 Spring and 2 fall & 17 May, 12 Aug, and 26 Aug \\
2 Spring and 2 fall & 17 May, 3 Jun, 12 Aug, and 26 Aug \\
\hline
\end{tabular}

${ }^{\mathrm{z}}$ Tebuconazole applied at $3.1 \mathrm{~kg} / \mathrm{ha}$ in 823 liters of $\mathrm{H}_{2} \mathrm{O}$ per hectare and followed by 10 to $13 \mathrm{~mm}$ irrigation.
Table 2. Dates of propiconazole applications to bermudagrass field plots with naturally occurring symptoms of spring dead spot in 2006 and $2007^{\mathrm{z}}$

\begin{tabular}{|c|c|}
\hline Application & Dates \\
\hline \multicolumn{2}{|l|}{2006} \\
\hline 1 Spring & $17 \mathrm{Apr}$ \\
\hline 2 Fall & 9 Sept and 9 Oct \\
\hline 1 Spring and 1 fall & 17 Apr and 9 Sept \\
\hline 1 Spring and 2 fall & $17 \mathrm{Apr}, 9 \mathrm{Sept}$, and 9 Oct \\
\hline \multicolumn{2}{|l|}{2007} \\
\hline 1 Spring & 2 May \\
\hline 2 Fall & 18 Sept and 18 Oct \\
\hline 1 Spring and 1 fall & 2 May and 18 Sept \\
\hline 1 Spring and 2 fall & 2 May, 18 Sept, and $18 \mathrm{Oct}$ \\
\hline
\end{tabular}


used for disease ratings to compare fungicide treatments to the nontreated control or to two fall application treatment. For change in disease area and percent area of plot with symptoms, treatment means were separated using Fisher's protected least significant difference (LSD) at $P \leq 0.05$. Pearson's correlation coefficient was performed between disease evaluation scale for inoculated studies determined 6 May 2005 and 15 May 2006, and between naturally infested plots on 16 May 2007 and 8 May 2008 and patch size or percent plot area affected, respectively.

\section{RESULTS}

Inoculated plots. As plants resumed growth in late April of 2005 and 2006, typical symptoms of spring dead spot appeared in nontreated control plots. No treatment by year interactions were found between experiments conducted from 2004 to 2006, and therefore data were combined and treatments examined over both years. For each evaluation date, orthogonal contrasts revealed that plots treated three or four times exhibited significantly lower disease severity than the nontreated plots (Table 3). Plots treated once in the spring and twice in the fall also exhibited significantly lower disease severity than the nontreated plots for the last three evaluation dates. For all evaluation dates, none of the fungicide treatment strategies using three or more applications were significantly different from two fall applications. Plots treated twice in the fall were not different from the nontreated plots on all evaluation dates; however, the change in patch size was significant for all fungicidetreated plots compared to the nontreated plots. Patches in plots treated four times were significantly smaller than patches treated once in the spring and twice in the fall or twice in the fall. A negative correlation $(r=-0.62, P=0.0001)$ was evident between disease rating and patch size.

Naturally infested field plots. As plants resumed growth in spring of 2007 and 2008, typical symptoms of spring dead spot began to appear in April in the fairway outside of the study area and in nontreated control plots. No treatment by year interactions were found between experiments conducted from 2006 to 2008, so all data were combined and treatments examined over both years. Orthogonal contrast revealed no treatment differences for the first observation date shortly after plants resumed growth. For all remaining evaluation dates, plots receiving two fall, one spring and one fall, or one spring and two fall fungicide applications exhibited significantly lower disease severity than nontreated plots (Table 4). With the exception of the first rating, there was no significant difference in disease severity for plots receiving two fall, one spring and one fall, or one spring and two fall fungicide applications.
When plots were evaluated at establishment for plot area affected by spring dead spot, there was no significant difference among all plots prior to the first application of treatments (Table 5). All plots receiving two fall, one spring and one fall, or one spring and two fall fungicide applications had significantly less area affected by disease than plots treated once in the spring or nontreated plots. For the change in diseased area from pre- to posttreatment, plots receiving two fall, one spring and one fall, or one spring and two fall fungicide applications had the greatest reduction in diseased area. A negative correlation $(r=-0.50, P=0.0009)$ was evident between disease rating and percent plot area affected by disease.

\section{DISCUSSION}

Effective management of spring dead spot through integrated approaches may require the use of fungicides. Many different fungicides are labeled for spring dead

Table 3. Effect of tebuconazole application timings for the control of spring dead spot of bermudagrass, 2004-2006

\begin{tabular}{|c|c|c|c|c|c|}
\hline \multirow[b]{2}{*}{ Treatment } & \multicolumn{4}{|c|}{ Disease rating $^{v}$} & \multirow{2}{*}{$\begin{array}{c}\text { Change in } \\
\text { disease area }\left(\mathrm{m}^{2}\right)^{\mathrm{x}}\end{array}$} \\
\hline & $1^{\mathrm{w}}$ & 2 & 3 & 4 & \\
\hline Nontreated control & 1.13 & 1.13 & 1.00 & 1.00 & $0.476 \mathrm{a}^{\mathrm{y}}$ \\
\hline 2 Fall & 2.50 & 2.63 & 2.44 & 2.75 & $0.109 \mathrm{~b}$ \\
\hline 3 Fall & $3.38 * \mathrm{z}$ & $3.50 *$ & $3.75 *$ & $3.75 *$ & $0.024 b c$ \\
\hline 4 Fall & $3.75 *$ & $3.88 *$ & $3.88 *$ & $3.88 *$ & $-0.090 \mathrm{c}$ \\
\hline 1 Spring and 2 fall & 2.88 & $3.00 *$ & $3.31 *$ & $3.63 *$ & $0.094 \mathrm{~b}$ \\
\hline 2 Spring and 2 fall & 2.75 & $3.00 *$ & 2.63 & 2.63 & $0.052 b c$ \\
\hline
\end{tabular}

${ }^{\mathrm{v}}$ Disease was evaluated on a scale of 1 to 6 , where $1=$ no living plants present in patch, $2=$ few surviving plants present in patch, $3=$ up to $50 \%$ of patch area containing living plants, $4=$ up to $75 \%$ of patch area containing living plants, $5=$ more than $75 \%$ of patch containing turfgrass and patch still evident, and $6=$ no evidence of diseased turfgrass. Data presented are means over years.

w Plots evaluated on: (1) 22 Apr and 22 Apr; (2) 29 Apr and 1 May; (3) 6 May and 5 May; (4) 13 May and 15 May of 2005 and 2006 , respectively.

${ }^{x}$ Patch area determined on 5 May 2005 and 24 May 2006 with change in patch area determined by subtracting patch area from that of the previous year.

${ }^{y}$ Means within the same column followed by the same letter are not significantly different $(P \leq 0.05)$ according to Fisher's protected least significant difference test.

${ }^{\mathrm{z}}$ Means followed by an asterisk are significantly different $(P \leq 0.05)$ from the nontreated control based on orthogonal contrast.

Table 4. Effect of propiconazole application timings for the control of spring dead spot of bermudagrass, 2006-2008

\begin{tabular}{lcccccc}
\hline & \multicolumn{7}{c}{ Disease rating $^{\mathbf{x}}$} \\
\cline { 2 - 7 } Treatment & $\mathbf{1}^{\mathbf{y}}$ & $\mathbf{2}$ & $\mathbf{3}$ & $\mathbf{4}$ & $\mathbf{5}$ & $\mathbf{6}$ \\
\hline Nontreated control & 2.38 & 2.00 & 2.00 & 1.88 & 1.88 & 2.13 \\
1 Spring & 2.50 & 2.00 & 2.00 & 1.75 & 1.63 & 1.75 \\
2 Fall & 3.13 & $4.13 * \mathrm{z}$ & $4.13 *$ & $4.13 *$ & $4.13 *$ & $4.50 *$ \\
1 Spring and 1 fall & 3.00 & $4.00 *$ & $3.63 *$ & $3.13 *$ & $4.13 *$ & $4.00 *$ \\
1 Spring and 2 fall & 3.38 & $3.63 *$ & $4.13^{*}$ & $4.13 *$ & $4.63 *$ & $4.50 *$ \\
\hline
\end{tabular}

${ }^{x}$ Disease was on a scale of 1 to 6 , where $1=$ no living plants present in patch, $2=$ few surviving plants present in patch, $3=$ up to $50 \%$ of patch area containing living plants, $4=$ up to $75 \%$ of patch area containing living plants, $5=$ more than $75 \%$ of patch containing turfgrass and patch still evident, and $6=$ no evidence of diseased turfgrass. Data presented are means over years.

y Plots evaluated on: (1) $11 \mathrm{Apr}$ and $9 \mathrm{Apr}$; (2) $18 \mathrm{Apr}$ and $16 \mathrm{Apr}$; (3) $25 \mathrm{Apr}$ and $23 \mathrm{Apr}$; (4) 2 May and $30 \mathrm{Apr}$; (5) 9 May and 8 May; and (6) 16 May and 14 May of 2007 and 2008, respectively.

${ }^{\mathrm{z}}$ Means followed by an asterisk are significantly different $(P \leq 0.05)$ from the nontreated control based on orthogonal contrast.

Table 5. Effect of propiconazole application timings on plot area affected by spring dead spot, 20062008

\begin{tabular}{lccc}
\hline & \multicolumn{2}{c}{ Area of plot expressing disease symptoms $(\%)^{\mathbf{x}}$} \\
\cline { 2 - 4 } Treatment & Pretreatment & Posttreatment $^{\mathbf{y}}$ & $\begin{array}{c}\text { Change } \\
\text { (pre- minus post-) }\end{array}$ \\
\hline Nontreated Control & 16.30 & $16.71 \mathrm{a}^{\mathrm{z}}$ & $0.45 \mathrm{a}$ \\
1 Spring & 16.56 & $20.09 \mathrm{a}$ & $3.50 \mathrm{a}$ \\
2 Fall & 14.85 & $2.80 \mathrm{~b}$ & $-12.05 \mathrm{~b}$ \\
1 Spring and 1 fall & 19.75 & $4.09 \mathrm{~b}$ & $-15.67 \mathrm{~b}$ \\
1 Spring and 2 fall & 22.37 & $3.64 \mathrm{~b}$ & $-18.73 \mathrm{~b}$ \\
\hline
\end{tabular}

${ }^{x}$ Percent plot area based on digital photographs analyzed using Assess software.

y Plots photographed on 16 May 2007 and 8 May 2008.

${ }^{\mathrm{z}}$ Means within the same column followed by the same letter are not significantly different $(P \leq 0.05)$ according to Fisher's protected least significant difference test. 
spot control, with most product labels recommending one or two fall applications. The effectiveness of fungicides to control spring dead spot has been described as inconsistent $(17,22)$. The reported inconsistent performance of fungicides has led to investigations of various methods to improve disease control using fungicides and to evaluate resulting disease severity or turfgrass quality $(2,3,7,20$, 21,25).

For inoculated plot studies, pretreated plots consisted of a single necrotic patch of similar size to ensure that treatments were evaluated equally. When size of the necrotic patch was determined posttreatment, clumps of living grass were often present inside the necrotic patches of fungicidetreated plots. For these plots when patch size was determined, measurements were taken to the patch interface zone between dead areas interspaced with living plants and outside the patch where the stand consisted of all living plants. This approach in determining patch size resulted in an increase in patch size for four of the five fungicide treatments. However, disease ratings were less for these treatments as a result of the numerous living plants in patches, and those surviving plants allowed for a more rapid recovery of the turfgrass stand later in the growing season.

Two triazole fungicides were selected for study based on their superior efficacy from a previous study (25). A change in active ingredient was made in 2006 for field studies based on delays in registration and approval of tebuconazole for use on turf and the similar performance of propiconazole which is approved for use on turf. Timing of field plot treatments with propiconazole was slightly changed to provide greater information on the effect of spring applications with and without fall applications.

Damage to plants by $O$. herpotricha occurs on roots, stolons or rhizomes, and crowns, and it is important to deliver fungicide effectively to the infected plant organs. In these studies, all applications were quickly followed by irrigation in an attempt to transport the products into the root zone prior to drying, and fairway applications were made in early morning when dew was present. For turfgrass managers who make fungicide applications for spring dead spot, morning applications when dew is present and activation of irrigation immediately after the grass is treated may increase the efficacy of the fungicide treatment.

For inoculated studies, two fall fungicide applications did not significantly reduce disease severity. Nitrogen fertility can influence the severity of spring dead spot $(8,11)$, with elevated rates or late-season applications leading to greater disease severities. Nitrogen fertility was greater for the inoculated patch studies than for the naturally infested fairway studies, with inoculated patches not treated with fungicide approaching $1 \mathrm{~m}^{2}$ or larger at the end of the study. These results suggest that for locations where spring dead spot is severe and nitrogen fertility is high, a reduction in disease severity may not be achieved with two fall fungicide applications. When the number of fall fungicide applications was increased, it did result in greater disease control; however, the cost of three or more applications to large areas of turf would be prohibitive. The addition of one or two spring applications to the standard two fall applications did not improve disease control.

A similar trend was observed for the studies conducted in naturally infested fairways, where one spring plus two fall applications were compared to two fall applications alone. However, one spring followed by one fall application was as effective as two fall applications with or without a spring application. A single fungicide application in the spring was not effective in reducing the severity of the disease the following year. The rate of spring bermudagrass recovery in those plots treated in the spring was not evaluated in this study. However, Butler and Tredway reported that spring treatments were not effective in increasing the rate of turfgrass recovery in the same season (2).

Given the cost of spring dead spot fungicide applications and concomitant performance expectations by turf managers, it is advisable for turfgrass managers to plot and photo document areas damaged by spring dead spot that may require a future fungicide application. Mapping of the affected area may provide for a better targeted fungicide application and reduce the application cost by avoiding application to areas not affected by the disease. Often managers have made fungicide applications and have expressed disappointment in the level of control. Without the inclusion of nontreated areas for comparison, it can be difficult for the manager to assess the efficacy of the fungicide applications. The use of photographs from one year to the next after a fungicide application may provide a manager with better evidence of disease suppression than just the damage caused by the disease present in the spring after treatment.

The results of these studies indicated that, as part of an integrated disease management program, a single application of fungicide in the spring should be followed by at least one fall application. Due to the cost of fungicide applications, two fall or one spring and one fall application appear to provide the most cost effective control of the disease. Effective use of fungicides in combination with appropriate integrated management tactics for spring dead spot over consecutive years may have an impact on primary inoculum and spread of the disease. This may reduce the long-term reliance on fungicides for disease control.
In addition, these studies demonstrate the importance of documenting the previous year's spring dead spot severity when evaluating a control measure and not just the severity present in nontreated plots at the time of evaluation.

\section{ACKNOWLEDGMENTS}

Published with the approval of the Director, Oklahoma Agricultural Experiment Station, Stillwater, OK. This project was supported in part by the Oklahoma Agricultural Experiment Station project 2420. The author thanks K. J. Black for technical assistance with this study.

\section{LITERATURE CITED}

1. Baird, J. H., Martin, D. L., Taliaferro, C. M. Payton, M. E., and Tisserat, N. A. 1998. Bermudagrass resistance to spring dead spot caused by Ophiosphaerella herpotricha. Plant Dis. 82:771-774.

2. Butler, E. L., and Tredway, L. P. 2004. Preventative control of spring dead spot in bermudagrass athletic fields, 2002-2003. Fungic Nematicide Tests 59:T027.

3. Butler, E. L., and Tredway, L. P. 2006. Method and timing of fungicide applications for control of spring dead spot in hybrid bermudagrass. Online. Plant Health Progress doi: 10.1094/PHP-2006-0901-01-RS.

4. Crahay, J. N., Dernoeden, P. H., and O'Neill, N. R. 1988. Growth and pathogenicity of Leptosphaeria korrae in bermudagrass. Plant Dis. 72:945-949

5. Dernoeden, P. H., Crahay, J. N., and Davis, D. B. 1991. Spring dead spot and bermudagrass quality as influenced by nitrogen source and potassium. Crop Sci. 31:1674-1680.

6. Endo, R. M., Ohr, H. D., Krausman, E. M. 1985. Leptosphaeria korrae, a cause of the spring dead spot disease of bermudagrass in California. Plant Dis. 69:235-237.

7. Luc, J. E., and Martin, S. B. 2006. Control of spring dead spot in Bermudagrass golf course fairways in South Carolina, 2004-2005. Fungic. Nematicide Tests 61:T011.

8. Lucas, L. T. 1980. Spring dead spot of bermudagrass. USGA Green Sec. Rec. 18:4-6.

9. Lucas, L. T. 1980. Spring dead spot of bermudagrass. Pages 183-187 in: Advances in Turfgrass Pathology. P. O. Larson and B. G. Joyner, eds. Harcourt Brace Jovanovich, Duluth, MN.

10. Martin, D. L., Bell, G. E., Baird, J. H., Taliaferro, C. M., Tisserat, N. A., Kuzmic, R. M., Dobson, D. D., and Anderson, J. A. 2001. Spring dead spot resistance and quality of seeded bermudagrasses under different mowing heights. Crop Sci. 41:451-456.

11. McCarty, L. B., Lucas, L. T., and DiPaola, J M. 1992. Spring dead spot occurrence in bermudagrass following fungicide and nutrient applications. HortScience 27:1092-1093.

12. Pair, J. C., Crowe, F. J., and Willis, W. G. 1986. Transmission of spring dead spot disease of bermudagrass by turf soil cores. Plant Dis. 70:877-878

13. Smiley, R. W., Dernoeden, P. H., and Clarke, B. C. 2005. Compendium of Turfgrass Disease. 3rd ed. American Phytopathological Society, St. Paul, MN.

14. Smith, A. M. 1965. Ophiobolus herpotrichus: A cause of spring dead spot in couch turf. Agric. Gaz. N.S.W. 76:753-758.

15. Smith, A. M. 1971. Control of spring deadspot of couch grass in New South Wales. J. Sports Turf Res. Inst. 47:60-65.

16. Smith, A. M. 1971. Spring dead spot of couch grass turf in New South Wales. J. Sports Turf Res. Inst. 47:54-59.

17. Tisserat, N. A. Spring dead spot of bermudagrass. Kansas State University. Online publica- 
tion. http://www.plantpath.ksu.edu/FCKUploa ds/File/Spring\%20Dead\%20Spot.pdf

18. Tisserat, N. A., and Fry, J. 1997. Cultural practices to reduce spring dead spot (Ophiosphaerella herpotricha) severity in Cynodon dactylon. Int. Turf. Res. J. 8:931-936.

19. Tisserat, N. A., Pair, J. C., and Nus, A. 1989. Ophiosphaerella herpotricha, a cause of spring dead spot of bermudagrass in Kansas. Plant Dis. 73:933-937.

20. Tredway, L. P., and Butler, E. L. 2005. Evaluation of fungicides for control of spring dead spot, 2003-2004. Fungic. Nematicide Tests 60:T014.

21. Tredway, L. P., Butler, E. L., Soika, M. D., and Bunting, M. L. 2008. Etiology and management of spring dead spot of hybrid bermuda- grass in North Carolina, USA. Acta Hortic. 783:535-546

22. Vincelli, P. Managing spring dead spot of bermudagrass. Online publication. http://www. ca.uky.edu/agc/pubs/id/id130/id130.htm.

23. Wadsworth, D. F., and Young, H. C. 1960. Spring dead spot of bermudagrass. Plant Dis. Rep. 44:516-518

24. Walker, J., and Smith, A. M. 1972. Leptosphaeria narmari and $L$. korrae sp. nov., two long-spored pathogens of grasses in Australia. Trans. Br. Mycol. Soc. 58:459-466.

25. Walker, N. R. 2005. Evaluation of fungicides for the management of spring dead spot of bermudagrass, 2003-2004. Fungic. Nematicide Tests 60:T022.

26. Walker, N. R., Mitchell, T. K., Morton, A. N., and Marek, S. M. 2006. Influence of temperature and time of year on colonization of bermudagrass roots by Ophiosphaerella herpotricha. Plant Dis. 90:1326-1330.

27. Wetzel, H. C. 2001. Evaluation of fungicides for control of spring dead spot of bermudagrass, 2000. Fungic. Nematicide Tests 56:T3.

28. Wetzel, H. C., III, Skinner, D. Z., and Tisserat, N. A. 1999. Geographic distribution and genetic diversity of three Ophiosphaerella species that cause spring dead spot of bermudagrass. Plant Dis. 83:1160-1166.

29. Young, H. C., Sturgeon, R. V. JR., and Huffine, W. W. 1973. Soil type associated with spring dead spot of bermudagrass. Phytopathology 63:450. 